\title{
ANALISA KEMANFAATAN DAN KEMUDAHAN TERHADAP PENERIMAAN SISTEM OPAC MENGGUNAKAN METODE TAM
}

\author{
Citra Kharismaya, Linda Sari Dewi , Ester Arisawati , Frisma Handayanna \\ Sekolah Tinggi Manajemen Informatika dan Komputer Nusa Mandiri \\ (STMIK Nusa Mandiri) \\ Jl. Kramat Raya No.18 Jakarta Pusat \\ http://www.nusamandiri.ac.id \\ Ckharismaya@gmail.com, linda.Irw@nusamandiri.ac.id, \\ esterarisawati@yahoo.com,frisma.fha@nusamandiri.ac.id
}

\begin{abstract}
ABSTRAK
Penelitian ini menggambarkan penerimaan OPAC variabel TAM Davis 1989 yakni perceived usefulness (kemanfaatan persepsian), perceived ease of use (kemudahan persepsian) dan accepted (penerimaan) OPAC. Dalam penelitian ini data dikumpulkan melalui kuesioner dengan menggunakan skala likert terhadap 100 respon den pengguna sistem OPAC (Online Public Access Catalog). Teknik sampling yang digunakan adalah purposive sampling guna mengetahui tingkat penerimaan system OPAC (Online Public Access Catalog). Analisis kuantitatif meliputi uji validitas, uji reliabilitas. Pada pengujian asumsi klasik, digunakan uji normalitas, multikolinearitas dan heterokedastisitas dengan pengujian hipotesis F dan $\mathrm{t}$. Analisis regresi linear berganda digunakan untuk mengetahui pengaruh antara variable independen dengan variable dependen. Hasil penelitian menunjukan bahwa kemanfaatan persepsian dan kemudahan persepsian memiliki pengaruh yang signifikan terhadap penerimaan system pengguna dengan( $R$ Square) sebesar $40,8 \%$.
\end{abstract}

Kata kunci: $T A M, O P A C$, Kemanfaatan, Kemudahan.

\section{ABSTRACT}

This study describes the reception OPAC Davis 1989 TAM variables namely perceived usefulness (perceived benefit), perceived ease of use (ease perceived) and accepted (acceptance) OPAC. In this study, data were collected through a questionnaire using Likert scale to 100 users si stem den response OPAC (Online Public Access Catalog). Sampling technique used is purposive sampling to determine the level of acceptance of the system OPAC (Online Public Access Catalog). Quantitative analysis includes the validity, reliability. In the classic assumption test, used test for normality, multicollinearity and heterokedastisitas with $F$ and $t$ hypothesis testing. Multiple linear regression analysis is used to determine the effect of the independent variables with the dependent variable. The results showed that perceived usefulness and perceived ease have a significant effect on the acceptance by the user system ( $R$ Square) amounted to $40.8 \%$.

Keywords: TAM, OPAC, usefulness,Ease. 


\section{PENDAHULUAN}

Seiring dengan perkembangan teknologi informasi dibidang perpustakaan pada dasarnya cenderung lebih menginginkan informasi cepat dan tepat dalam mendapatkan informasi, mudah dalam mengakses, praktis dan efisien serta efektivitas yang berdampak pada peningkatan produktivitas. Dalam hal ini Perpustakaan Nasional Republik Indonesia memiliki misi untuk mengembangkan layanan perpustakaan berbasis teknologi informasi dan komunikasi (TIK). Salah satunya dengan membuat sistem informasi untuk menelusur keberadaan bahanpustaka yaitu OPAC (Online Public Access Catalog) dengan sistem jaringan yang diimpelementasikan pada tahun 2004.

(Online Public Access Catalog) adalah sebuah fitur yang digunakan untuk memfasilitasi pengunjung untuk mencari katalog koleksi perpustakaan yang dapat diakses oleh umum[4]. Katalog on-line ialah katalog yang terpasang pada komputer biasanya dihubungkan dengan sistem jaringan baik jaringan Local Area Network (LAN) ataupun jaringan dalam skala yang luasWide Area Network (WAN)[1]. Katalog on-line juga disebut dengan OPAC (Online Public Access Catalog).

OPAC (Online Public Access Catalog) merupakan katalog penelusuran untuk mencari informasi yang dibutuhkan pemustaka supaya lebih cepat. Pemustaka hanya mengetikkan keyword data koleksi yang ingin dicari ke dalam kolom yang tersedia dalam program OPAC, selanjutnya akan muncul pilihan dari data koleksi yang ingin di cari pemustaka.

Tujuan dari penelitian ini adalah untuk mengetahui sejauh mana penerimaan teknologi perpustakaan dapat diterima oleh pengguna sejak dimunculkannya sistem informasi OPAC. Proses penerimaan sistem informasi OPAC dapat dianalisis dengan menggunakan metode Technology Acceptance Model (TAM). Dimana proses penerimaan sistem informasi oleh pengguna dipengaruhi oleh kemanfaatan persepsian (Perceived Usefulness) serta kemudahan persepsian penggunaan (Perceived Ease Of Use) [2].

\section{METODOLOGI PENELITIAN}

\subsection{TAM (Technology Acceptance Model)}

Model Penerimaan Teknologi (Technology Acceptance Model atau TAM) merupakan suatu model penerimaan sistem teknologi informasi yang akan digunakan oleh pemakai[2]. Model penerimaan teknologi atau Technology Acceptance Model (TAM) berdasarkan model TRA. TAM menambahkan dua konstruk utama ke dalam model TRA. Dua konstruk utama ini adalah kemanfaatan persepsian (perceived usefulness) dan Kemudahan penggunaan persepsian (perceived easy of use).

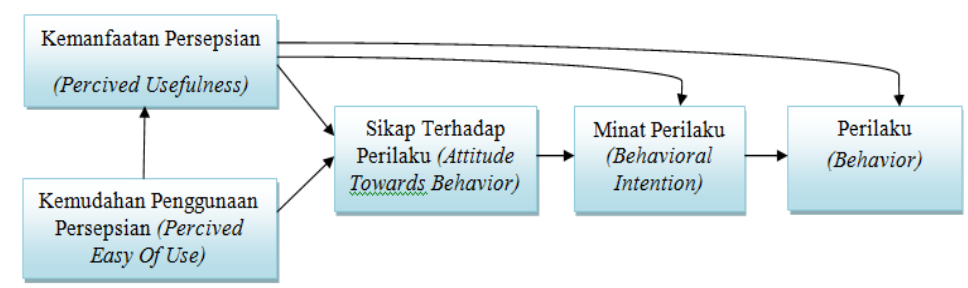

Gambar 1. Technology Acceptance Model (TAM)

\subsection{Penerimaan Sistem}

Intensitas penggunaan sistem dapat digantikan oleh variabel penerimaan terhadap TI (Acceptanceof IT)[3]. Sehingga model Penerimaan Teknologinya seperti terlihat pada gambar sebagai berikut: 


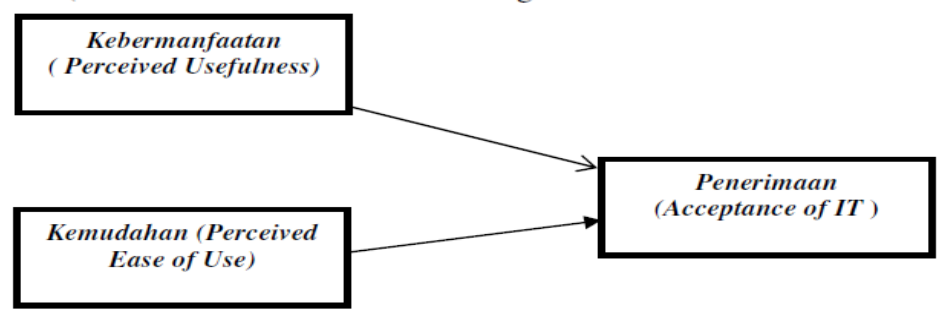

Gambar 2. Model Penerimaan Teknologi

\subsection{Metode Penelitian}

Penelitian dilakukan dengan metode penelitian kuantitatif. Dalam penelitian ini menggunakan 2 variabel independen, yaitu: Kemanfaatan persepsian (perceived usefulness), Kemudahan persepsian (perceived easy of use) dan 1 variabel dependen, yaitu: penerimaan terhadap TI (Acceptanceof IT).

Penelitian ini dimulai dari proses pengumpulan data yang berupa kuesioner yang diisi oleh responden yang kemudian dilakukan Uji Validitas dan Uji Reliabilitas terhadap kuesioner tersebut. Selanjutnya setelah kuesioner dianggap valid dan reliabel, maka pengumpulan data dilakukan kembali.

Langkah pengujian dimulai dengan Uji Asumsi Klasik, yaitu: Uji Normalitas, Uji Multikolinearitas dan Uji Heterokedastisitas. Hasilnya kemudian di lakukan analisis data untuk menguji pengaruh kedua variabel penentu penerimaan teknologi dengan menggunakan Regresi Linear Berganda dan dilanjutkan dengan analisis-analisis, yaitu:

1) Uji t,untuk mengetahui apakah secara parsial kemudahan, kemanfaatan berpengaruh secara signifikan atau tidak terhadap variabel penerimaan sistem.

2) Uji F, merupakan uji koefisien regresi secara bersama-sama untuk menguji signifikansi pengaruh beberapa variabel independen terhadap dependen.

3) Koefisien determinasi, bertujuan untuk mengukur seberapa jauh kemampuan model dalam menerangkan variasi variabel dependen.

4) Koefisien determinasi parsial, digunakan untuk mengetahui seberapa besar sumbangan dari masing-masing variabel independen terhadap variabel dependen. Perhitungan analisis ini menggunakan software SPSS 23.0.

\section{HASIL DAN PEMBAHASAN}

\subsection{Uji Validitas}

Jika $r_{\text {hitung }}>r_{\text {tabel, }}$, maka pernyataan tersebut dapat dinyatakan valid. Hasil pengujian validitas untuk setiap variabel ditampilkan pada tabel berikut.

\section{a. Kemanfaatan Persepsian}

Terdapat enam butir pernyataan yang ditunjukan oleh Corrected Item-Total Correlation

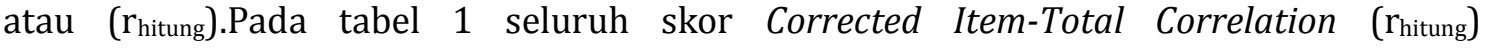
menunjukan lebih besar dari $r_{\text {tabel }}$ sebesar 0,197.Hal ini menunjukan bahwa setiap pernyataan yang diukur pada variabel kemanfaatan persepsian adalah valid. 
Tabel 1. Hasil Uji Validitas Kemanfaatan Persepsian

\begin{tabular}{|c|c|c|c|}
\hline No & $\begin{array}{c}\text { R hitung (Corrected Item Total } \\
\text { Correlation) }\end{array}$ & R tabel & Kesimpulan \\
\hline 1 & 0,725 & 0,197 & Valid \\
\hline 2 & 0,773 & 0,197 & Valid \\
\hline 3 & 0,709 & 0,197 & Valid \\
\hline 4 & 0,694 & 0,197 & Valid \\
\hline 5 & 0,625 & 0,197 & Valid \\
\hline 6 & 0,698 & 0,197 & Valid \\
\hline
\end{tabular}

b. Kemudahan Persepsian

Terdapat enam butir pernyataan yang ditunjukan oleh Corrected Item-Total

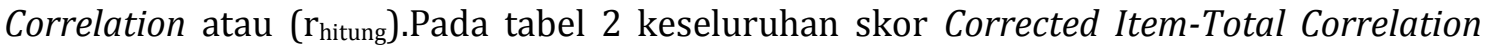
( $r_{\text {hitung}}$ ) menunjukan lebih besar dari $r_{\text {tabel }}$ sebesar 0,197. Hal ini menunjukan bahwa setiap butir pernyataan yang diukur pada variabel kemudahan Persepsian adalah valid.

Tabel 2. Hasil Uji Validitas Kemudahan Persepsian

\begin{tabular}{|l|c|c|c|}
\hline No & $\begin{array}{c}\text { R hitung (Corrected Item Total } \\
\text { Correlation) }\end{array}$ & R tabel & Kesimpulan \\
\hline 1 & 0,750 & 0,197 & Valid \\
\hline 2 & 0,802 & 0,197 & Valid \\
\hline 3 & 0,846 & 0,197 & Valid \\
\hline 4 & 0,830 & 0,197 & Valid \\
\hline 5 & 0,693 & 0,197 & Valid \\
\hline 6 & 0,710 & 0,197 & Valid \\
\hline
\end{tabular}

c. Penerimaan Sistem

Terdapat tiga butir pernyataan yang ditunjukan oleh Corrected Item-Total Correlation atau ( $\mathrm{r}_{\text {hitung. }}$ ).Pada tabel 3 skor Corrected Item-Total Correlation ( $\mathrm{r}_{\text {hitung }}$ ) menunjukan lebih besar dari $r_{\text {tabel. }}$ Hal ini menunjukan bahwa setiap pernyataan yang diukur pada variabel penerimaan sistem adalah valid.

Tabel 3. Hasil Uji Validitas Penerimaan Sistem

\begin{tabular}{|l|c|c|c|}
\hline No & $\begin{array}{c}\text { R hitung (Corrected Item Total } \\
\text { Correlation) }\end{array}$ & R tabel & Kesimpulan \\
\hline 1 & 0,763 & 0,197 & Valid \\
\hline 2 & 0,756 & 0,197 & Valid \\
\hline 3 & 0,733 & 0,197 & Valid \\
\hline
\end{tabular}

\subsection{Uji Reliabilitas}

Uji reliabilitas dari setiap variabel yang digunakan dalam penelitian ini menggunakan metode Cronbach's Alpha. Pengujian instrumen dinyatakan reliabel, jika harga koefisien reliabilitas $>0,60$.

Tabel 4. Hasil Uji Reabilitas

\begin{tabular}{|l|c|c|c|}
\hline \multicolumn{1}{|c|}{ Yariabel } & $\begin{array}{c}\text { Cronbach's } \\
\text { Alpha }\end{array}$ & $\begin{array}{c}\text { Cronbach's Alpha } \\
\text { yang disyaratkan }\end{array}$ & \\
\hline Kemanfaatan $\left(\mathrm{X}_{1}\right)$ & 0,797 & $>0,60$ & Reliabel \\
\hline Kemudahan $\left(\mathrm{X}_{2}\right)$ & 0,864 & $>0,60$ & Reliabel \\
\hline Penerimaan Sistem $(\mathrm{Y})$ & 0,607 & $>0,60$ & Reliabel \\
\hline
\end{tabular}


Berdasarkan tabel 4 diketahui bahwa variabel X1, X2 dan Y memiliki Ccronbach's Alpha lebih besar dari 0,60 yang artinya data reliabel.

\subsection{Uji Asumsi Klasik}

a. Hasil Uji Normalitas

Statistik uji yang digunakan adalah One-Sample Kolmogrov Smirnov Test didasarkan pada nilai Asymp.Sig. (2-tailed) dengan ketentuan jika Asymp. Sig.(2-tailed) >alpha yang ditetapkan sebelumnya sebesar $(0,05)$ maka data berdistribusi normal dan sebaliknya jika $<$ alpha yang ditentukan, maka data tidak berdistribusi normal.

Tabel 5. Hasil Uji Validitas Penerimaan Sistem

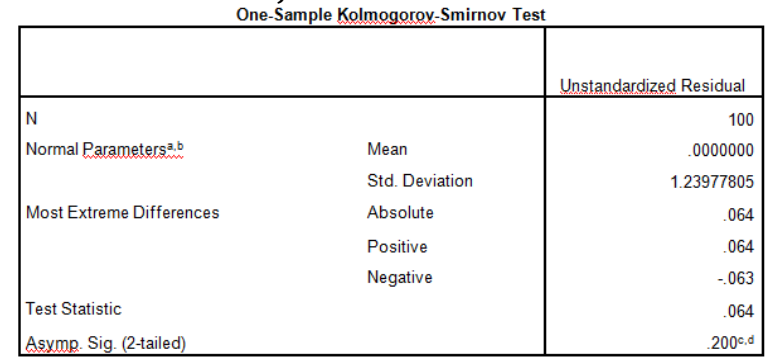

Berdasarkan tabel 5 Asymp.Sig. (2-tailed) sebesar 0,200.Hal ini menunjukan bahwa Asymp. Sig. (2-tailed) sebesar 0,200>0,05 yang berarti data berdistribusi normal. Disamping dengan menggunakan uji Kolmogorof-Smirnov, uji normalitas ini juga didukung dari hasil gambar Normal Probability Plot. Apabila variabel berdistribusi normal maka penyebaran plot akan berada disekitar dan sepanjang garis 45 derajat.

Hasil dari uji normalitas (grafik Normal Probability Plot) dengan menggunakan SPSS adalah sebagai berikut:

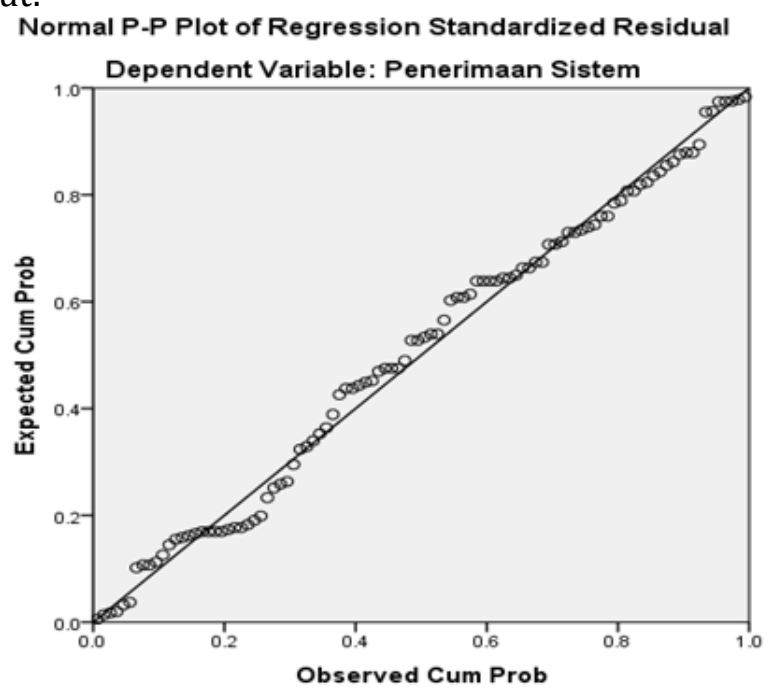

Gambar 3. Hasil Uji Normalitas P-plot

Pada Gambar 3 menunjukan bahwa grafik P-pot terlihat data menyebar disekitar garis diagonal dan mengikuti arah garis diagonal,yang berarti data berdistribusi normal.

b. Hasil Uji Multikolinearitas

Uji multikolinearitas bertujuan untuk menguji apakah model regresi ditemukan adanya korelasi antar variabel bebas. Model regresi yang baik seharusnya tidak terjadi multikolinearitas, jika VIF lebih kecil dari 10 dan mempunyai angka tolerance lebih besar dari 0,10. 
Tabel 6. Hasil Uji Multikolinearitas

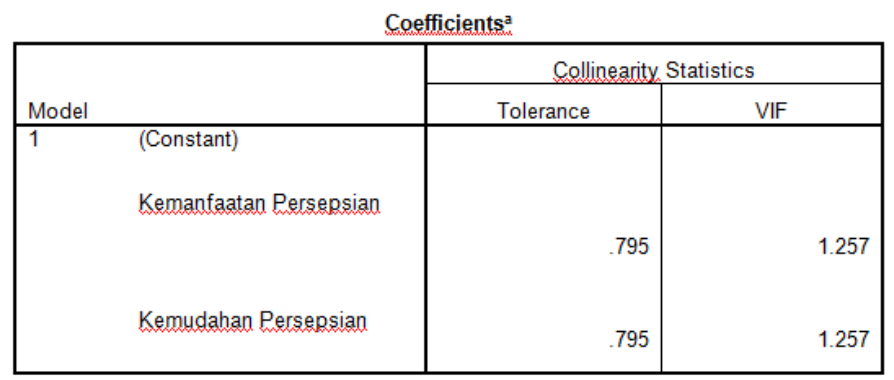

Berdasarkan Tabel 6 menunjukan variabel kemanfaatan persepsian (X1) memiliki nilai tolerance sebesar 0,795 dan nilai VIF 1,257.variabel kemudahan persepsian (X2) memiliki nilai tolerance 0,795 dan nilai VIF 1,257 .

Berdasarkan hasil uji multikolinearitas pada tabel tersebut, maka seluruh variabel independen pada model regresi memiliki nilai tolerance $\geq 0,10$ dan nilai VIF $\leq 10$. Hal ini memenuhi asumsi bahwa tidak terjadi multikolinearitas.

c. Hasil Uji Heteroskedastisitas

Pada penelitian ini untuk mendeteksi adanya heteroskedastisitas digunakan grafik scatterplot antara nilai variabel terikat (ZPRED) dengan residualnya (SRESID). Adapun kriteria pengambilan keputusan untuk menguji heteroskedastisitas melalui grafik scatterplot, yaitu:

Jika grafik scatterplot menunjukan pola titik seperti titik yang bergelombang atau melebar kemudian menyempit, maka dapat disimpulkan bahwa telah terjadi heteroskedastisitas.

Jika grafik scatterplot tidak membentuk pola yang jelas dan penyebaran data terjadi diatas dan dibawah angka 0 pada sumbu Y maka dapat dikatakan model regresi tersebut tidak terjadi heteroskedastisitas.

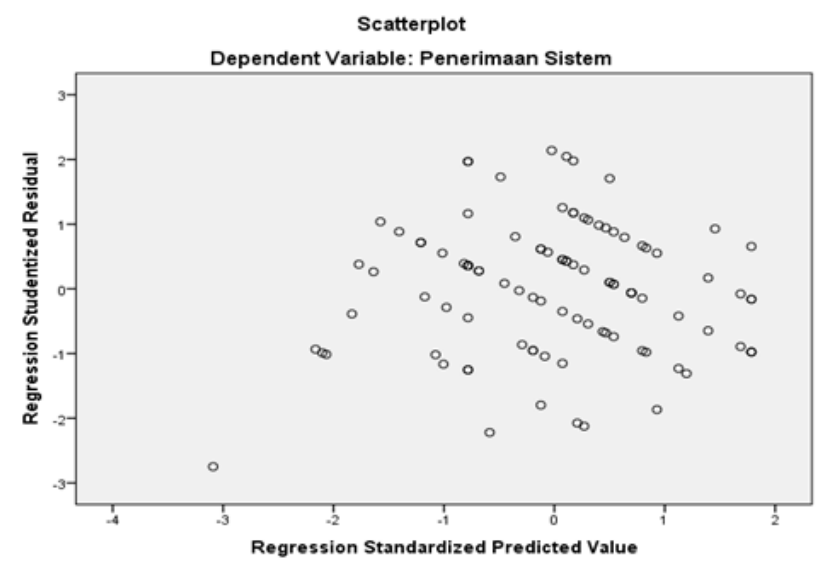

Gambar 4. Hasil Uji Heteroskedastisitas

Dari output gambar 4 dapat diketahui bahwa titik-titik tidak membentuk pola yang jelas. Titik-titik menyebar di atas dan dibawah angka 0 dan Y. Jadi, dapat disimpulkan bahwa tidak terjadi heteroskedastisitas dalam model regresi.

d. Hasil UjiRegresi Linear Berganda

Bentuk model prediksi yang telah diperoleh dengan metode regresi linear berganda menghasilkan nilai pada tabel 7 
Tabel 7. Hasil Uji Regresi Linear Berganda

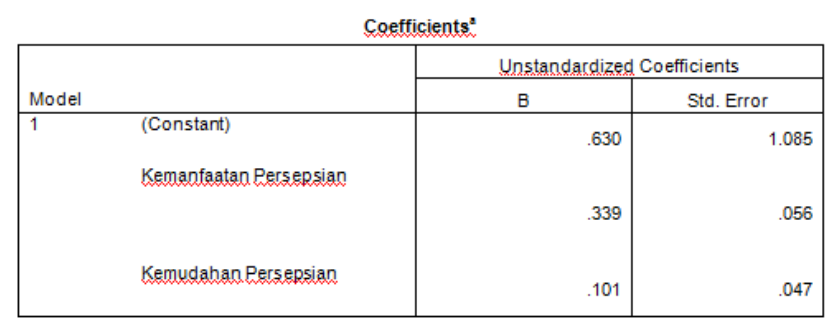

Berdasarkan tabel 7 diatas, maka diperoleh persamaan regresi sebagai berikut:

$$
\mathrm{Y}=0,630+0,339 \mathrm{X}_{1}+0,101 \mathrm{X}_{2}
$$

Dengan $X_{1}=$ kemanfaatan persepsian, $X_{2}=$ kemudahanpersepsian dari persamaan regresi tersebut memiliki arti sebagai berikut:

a. Nilai konstanta $(\alpha)$ sebesar 0,630, artinya jika semua variabel independen kemanfaatan persepsian $\left(\mathrm{X}_{1}\right)$, kemudahan persepsian $\left(\mathrm{X}_{2}\right)$ sama dengan nol $(0)$, maka penerimaan sistem bernilai 0,630 .

b. Nilai koefisien regresi variabel kemanfaatan $\left(\mathrm{X}_{1}\right)$ 0,334 artinya setiap peningkatan kemanfaatan OPAC (Online Public Access Catalog) sebesar satu satuan akan meningkatkan penerimaan sistem sebesar 0,334 dengan asumsi variabel lain bernilai tetap.

c. Nilai koefisien regresi variabel kemudahan persepsian $\left(\mathrm{X}_{2}\right)$ bernilai 0,101 yang artinya setiap peningkatan kemudahan OPAC (Online Public Access Catalog) sebesar satu satuan akan meningkatkan penerimaan sistem sebesar 0,101 dengan asumsi variabel yang lain bernilai tetap.

\subsection{Hasil Uji Hipotesis}

\section{a. Hasil Uji F}

Uji F merupakan uji koefisien regresi secara bersama-sama untuk menguji signifikansi pengaruh beberapa variabel independen terhadap dependen.Dalam hal ini peran uji $\mathrm{F}$ untuk menguji signifikansi pengaruh kemudahan, kemanfaatan secara bersama-sama terhadap penerimaan sistem. Kriteria pengujian uji F sebagai berikut:

a. Jika, $F_{\text {hitung }}>F_{\text {tabel }}$ maka regresi memiliki keberartian (signifikan) sedangkan bila $\mathrm{F}_{\text {hitung }}<\mathrm{F}_{\text {tabel }}$ maka regresi tidak memiliki signifikansi.

b. Berdasarkan nilai probabilitas signifikansi, apabila nilai probabilitas signifikansi $>$ 0,05 maka dinyatakan tidak memiliki keberartian atau tidak signifikan, sedangkan jika nilai probabilitas signifikansi $<0,05$ maka regresi memiliki signifikansi.

Hasil Pengujian Hipotesis:

$\mathrm{H}_{0}$ : Tidak terdapat pengaruh secara signifikan antara kemanfaatan persepsian (perceived usefulness) dan kemudahan persepsian (perceived ease ofuse) secara bersamasama terhadappenerimaan sistem OPAC (Online Public Access Catalog).

$\mathrm{H}_{\mathrm{a}}$ : Terdapat pengaruh secara signifikan antara kemanfaatan persepsian (perceived usefulness) dan kemudahan persepsian (perceived ease ofuse)secara bersama-sama terhadappenerimaansistem OPAC (Online Public Access catalog). 
Tabel 8. Hasil Uji F

ANOVA:

\begin{tabular}{|c|r|r|r|r|r|}
\hline \multicolumn{1}{|c|}{ Model } & Sum of Squares & Df & Mean Square & F & Sig. \\
\hline $1 \quad$ Regression & 104.872 & 2 & 52.436 & 33.426 & $.000^{\circ}$ \\
Residual & 152.168 & 97 & 1.569 & & \\
Total & 257.040 & 99 & & & \\
& & & & & \\
\hline
\end{tabular}

Berdasarkan tabel 8 diperoleh nilai $\mathrm{F}_{\text {hitung }}$ sebesar 33,426 dan nilai $\mathrm{F}_{\text {tabel }}$ sebesar 3,090 yang berarti $F_{\text {hitung }}>F_{\text {tabel }}$ atau 33,426> 3,090. Hasil ini menunjukan bahwa terdapat pengaruh secara signifikan antara kemanfaatan persepsian dan kemudahan persepsian terhadap penerimaan sistem OPAC (Online Public Access Catalog).

Selain itu, dapat dilihat berdasarkan nilai signifikansi sebesar 0,000 0,05 maka, dapat dikatakan koefisien regresi signifikan.

\section{b. Hasil Uji T}

Uji t digunakan untuk mengetahui apakah secara parsial kemanfaatan persepsian dan kemudahan persepsian berpengaruh secara signifikan atau tidak terhadap variabel penerimaan sistem.

Tabel 9. Hasil Uji T

Coefficients:

\begin{tabular}{|c|c|c|c|}
\hline Model & & $\mathrm{T}$ & Sig. \\
\hline & $\begin{array}{l}\text { (Constant) } \\
\text { Kemanfaatan Persepsian }\end{array}$ & .581 & .563 \\
\hline & Kemudahan Rersepsian & 6.066 & .000 \\
\hline & & 2.146 & .034 \\
\hline
\end{tabular}

a. Berdasarkan perhitungan SPSS, untuk nilai $t_{\text {hitung }} \mathrm{X} 1$ adalah 6,066 dan nilai $t_{\text {tabel }}$ sebesar 1,661 dengan tingkat signifikansi sebesar 0,05. Hasil ini menunjukan perbandingan antara $t_{\text {hitung }}$ dengan $t_{\text {tabel }}$ yaitu 6,066 $>1,661$ dan perbandingan tingkat signifikansi $0,000<0,05$. Dapat diambil kesimpulan bahwa variabel kemanfaatan persepsian memiliki pengaruh yang signifikan terhadap penerimaan sistem OPAC (Online Public Access Catalog).

b. Berdasarkan perhitungan SPSS, untuk nilai thitung $X_{2}$ adalah 2,146 dan nilai

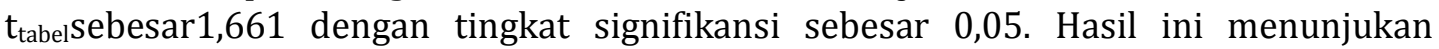
perbandingan antara $t_{\text {hitung }}$ dengan $t_{\text {tabelyaitu }} 2,146>1,661$ dan perbandingan tingkat signifikansi 0,034 < 0,05. Dapat diambil kesimpulan bahwa variabel kemudahan persepsian memiliki pengaruh yang signifikan terhadap penerimaan sistem OPAC (Online Public Access Catalog).

\section{c. Koefisien Determinasi Simultan $\left(\mathbf{R}^{2}\right)$}

Koefisien determinasi bertujuan untuk mengukur seberapa jauh kemampuan model dalam menerangkan variasi variabel dependen.Nilai koefisien determinasi antara nol dan satu.Nilai koefisien determinasi dapat dilihat pada tabel 10. 
Tabel 10. Hasil Uji Koefisien Determinasi Simultan Model Summarx ${ }^{\circ}$

\begin{tabular}{|l|r|r|r|r|}
\hline & & & & \\
Model & $\mathrm{R}$ & $\mathrm{R}$ Square & $\begin{array}{c}\text { Adjusted R } \\
\text { Square }\end{array}$ & $\begin{array}{c}\text { Std. Error of the } \\
\text { Estimate }\end{array}$ \\
\hline 1 & $.639^{*}$ & .408 & .396 & 1.252 \\
\hline
\end{tabular}

Hasil perhitungan dengan menggunakan program spss dapat diketahui bahwa koefisien determinasi ( $R$ Square) yang diperoleh sebesar 0,408. Hal ini berarti 40,8\% penerimaan sistem OPAC (Online Public Access Catalog)dapat dijelaskan oleh variabel kemanfaatan persepsian dan kemudahan persepsian. Sedangkan sisanya 50,2\% dipengaruhi oleh variabel-variabel lain yang tidak diteliti dalam penelitian ini.

\section{d. Koefisien Determinasi Parsial $\left(\mathbf{r}^{2}\right)$}

Koefisien determinasi parsial digunakan untuk mengetahui seberapa besar sumbangan dari masing-masing variabel independen terhadap variabel dependen. Secara parsial kemanfaatan persepsian dan kemudahan persepsian terhadap penerimaan sistem dapat dilihat pada tabel berikut ini:

Tabel 11. Hasil Uji Koefisien Determinasi Parsial Coefficients"

\begin{tabular}{|l|r|r|r|}
\hline \multirow{2}{*}{ Model } & \multicolumn{3}{|c|}{ Correlations } \\
\cline { 2 - 4 } & Zero-order & Partial & Part \\
\hline $1 \quad$ (Constant) & & & \\
Kemanfaatan Persepsian & .616 & .524 & .474 \\
& & & \\
Kemudahan Persepsian & .428 & .213 & .168 \\
\hline
\end{tabular}

Berdasarkan tabel 11, diketahui besarnya $r^{2}$ kemanfaatan persepsian adalah $27,4 \%$ yang diperoleh dari koefisien korelasi parsial untuk variabel kemanfaatan persepsian dikuadratkan yaitu $(0,524)^{2}$. Besarnya pengaruh kemudahan persepsian adalah 45,3\% yang diperoleh dari koefisien korelasi parsial untuk variabel kemudahan persepsian dikuadratkan yaitu $(0,213)^{2}$. Dari penjelasan tersebut menunjukan bahwa kemanfaatan persepsian memberikan pengaruh lebih kecil terhadap penerimaan sistem dibandingkan dengan kemudahan persepsian.

Pada pengujian validitas menunjukan bahwa $r_{\text {hitung }}$ dari masing-masing variabel lebih besar dari $r_{\text {tabel }}$ sebesar 0,197 dan tingkat signifikansi dari masing-masing variabel kurang dari 0,05. Hasil pengujian yang telah dilakukan sebagai berikut:

1. Variabel Kemanfaatan Persepsian

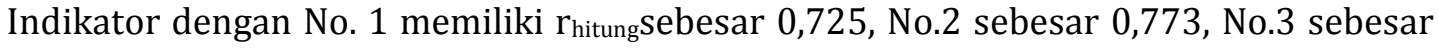
0,709, No.4 sebesar 0,694, No.5 sebesar 0,625 dan No.6 sebesar 0,698 dengan tingkat signifikasi dari masing-masing sebesar 0,000. Variabel kemanfaatan dengan 6 butir indikator dinyatakan valid.

2. Variabel Kemudahan Persepsian 
Indikator dengan No. 1 memiliki $\mathrm{r}_{\text {hitung }}$ sebesar 0,750, No.2 sebesar 0,802, No.3 sebesar 0,846, No.4 sebesar 0,830, No.5 sebesar 0,693 dan No.6 sebesar 0,710 dengan tingkat signifikasi dari masing-masing sebesar 0,000. Variabel kemudahan dengan 6 butir indikator dinyatakan valid.

3. Variabel Penerimaan Sistem

Indikator dengan No. 1 memiliki $r_{\text {hitungsebesar }}$ 0,763, No.2 sebesar 0,756 dan No.3 sebesar 0,733 dengan tingkat signifikasi dari masing-masing sebesar 0,000. Variabel kemanfaatan dengan 3 butir indikator dinyatakan valid.

Kemudian pada uji reliabilitas menunjukan bahwa nilai Cronbach's Alphadari tiap konstruk atau variabel lebih besar dari 0,60 yang berarti bahwa kuesioner yang merupakan indikator dari variabel adalah reliabel atau handal. Hal tersebut dapat dilihat dari hasil pengujian yang telah dilakukan dengan Cronbach's Alphauntuk kemanfaatan persepsian sebesar 0,797 , kemudahan persepsian sebesar 0,864 dan penerimaan sistem 0,607 .

Sementara itu, dari hasil uji t menyatakan bahwa variabel kemanfaatan persepsian memiliki pengaruh secara signifikan terhadap penerimaan sistem pengguna berdasarkan hasil output spss yang menunjukan bahwa thitung 6,066 lebih besar dari tabel 1,661 dan signifikasi dibawah dari 0,05 yaitu sebesar 0,000. Kemudian pada kemudahan persepsian

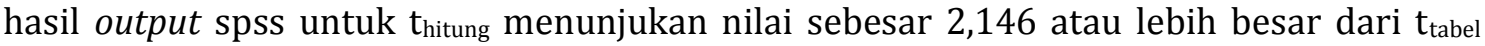
sebesar 1,661 dengan signifikansi sebesar 0,034 lebih kecil dari 0,05 memiliki pengaruh yang signifikan terhadap penerimaan sistem OPAC (Online Public Access Catalog) di Perpustakaan Nasional Republik Indonesia.

Sementara pada hasil perhitungan lainnya yaitu Koefisien Determinasi $\left(R^{2}\right)$, dapat disimpulkan bahwa variabel independen dalam penelitian ini mampu menerangkan sebesar 0,408 atau sebesar 40,8\% mengenai penerimaan sistem OPAC (Online Public Access Catalog). Sedangkan sisanya 50,2\% dijelaskan oleh variabel lain yang tidak dimasukkan dalam penelitian ini.

Hasil pengujian hipotesis sebagai berikut:

Ho : Tidak terdapat pengaruh secara signifikan antara kemanfaatan persepsian (perceived usefulness) dan kemudahan persepsian (perceived ease ofuse)secara bersama-sama terhadappenerimaan sistem OPAC (Online Public Access Catalog).

Ha : Terdapat pengaruh secara signifikan antara kemanfaatan persepsian (perceived usefulness) dan kemudahan persepsian (perceived ease ofuse)secara bersama-sama terhadappenerimaan sistem OPAC (Online Public Access Catalog).

Hasil uji F menunjukan bahwa pengaruh secara bersamaan dari seluruh variabel independen (kemanfaatan persepsian dan kemudahan persepsian) terhadap penerimaan sistem pengguna OPAC (Open Public Access Catalog)di Perpustakaan Nasional Republik Indonesia menunjukan hasil yang signifikan. Hal tersebut dari besarnya nilai $\mathrm{F}$ sebesar 33,426 dengan tingkat signifikansi 0,000 kurang dari 0,05.

\section{KESIMPULAN}

Berdasarkan pembahasan seperti yang telah diuraikan dapat ditarik kesimpulan bahwa:

a. Berdasarkan hasil penelitian, pada analisis regresi menunjukan nilai $F_{\text {hitung }}$ sebesar 33,426 dengan tingkat signifikan 0,05 pada uji $F$ diperoleh nilai sebesar 0,000 atau kurang dari 0,05. Hal ini menunjukan bahwa variabel kemanfaatan persepsian memiliki pengaruh signifikan terhadap penerimaan sistem OPAC (Online Public Access Catalog). 
b. Hasil output spss pada uji t menyimpulkan bahwa variabel kemanfaatan persepsian memiliki nilai $t_{\text {hitungsebesar } 6,066}$ dan kemudahan persepsian memiliki nilai

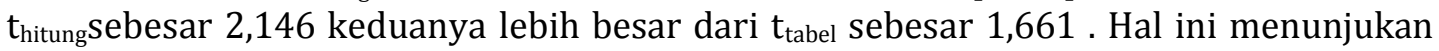
bahwa variabel kemanfaatan persepsian memiliki pengaruh signifikan terhadap penerimaan sistem OPAC (Online Public Access Catalog).

c. Variabel independen dalam penelitian ini mampu menerangkan sebesar 0,408 atau sebesar 40,8\% mengenai penerimaan sistem OPAC (Online Public Access Catalog). Sedangkan sisanya 50,2\% dijelaskan oleh variabel lain yang tidak dimasukkan dalam penelitian ini.

\section{DAFTAR PUSTAKA}

[1] Darmono. 2007. Perpustakaan Sekolah: pendekatan aspek manajemen dan tata kerja. Jakarta : Grasindo

[2] Jogiyanto, 2008. Sistem Informasi Keperilakuan. Yogyakarta: Andi Offset.

[3] Nurtantino, Andri, Heny Kurnianingsih, Hestin Mutmainah. 2015. Analisis Penerimaan Teknologi Perpustakaan Digital Pada Perpustakaan Perguruan Tinggi Swasta di Sukoharjo. ISSN : 1693-0827. Surakarta: Jurnal Paradigma

[4] Supriyanto, Wahyudan Ahmad Muhsin. 2008. Teknologi Informasi Perpustakaan. Yogyakarta: Kanisius. 